\title{
Using student questions to direct information literacy workshops
}

\section{Introduction}

What do university students really want to know about the library? When faced with their first semester of teaching in-class information literacy workshops, two early career liaison librarians at McGill University in Montreal, Canada contemplated this basic question. As a new librarian, preparing for information literacy workshops can be challenging. With little or no experience in lesson planning or teaching, new librarians must imagine how best to engage students, cover the appropriate content, and deal with time restrictions that are sometimes limiting. Planning in-class information literacy workshops often requires conjecture as the librarians anticipate how much research experience or library exposure students in a particular class may have. Although discussions with the professor, consideration of the level of study (undergraduate or graduate? freshman or senior?), the time of the year (first week of the fall semester or assignment time?), and the type of assignments help the librarian to anticipate the questions students may have about the library and library research, a more straightforward solution is to ask the students directly.

Thus, the authors were inspired to use student questions as an ice-breaker activity in their in-class information literacy workshops. The authors started their workshops by asking students to write down a "burning question" they had about the library or about library research. The questions were then collected, quickly read by the librarian, and used to inform the content of the workshop. Efforts were made to answer each of the students' questions during the workshop. Following each workshop, the students' questions were recorded for further analysis. This activity was engaging for the students and it also helped the authors to gauge the students' library knowledge, thereby helping to eliminate some of the authors' assumptions regarding students' concerns and queries about the library and research.

This paper will discuss how the simple "burning question" ice-breaker activity can be used as a valuable instruction strategy in university-level information literacy workshops. By adding this activity to their teaching toolkit, librarians can create more flexible and relevant information literacy workshops while simultaneously increasing student engagement. Best practices for using this strategy will also be discussed.

\section{Literature Review}

\section{Engaging Students in Information Literacy (IL) Workshops: Making the Best First Impression}

Librarians work to promote the merits of information literacy instruction to faculty, understanding information literacy skills to be essential to students' academic development during their years of study and beyond. While information literacy and the Association of College and Research Library's (ACRL) standards are increasingly being valued at an institutional level, librarians still report that course instructors can be resistant to "give up" class time to librarians (Badke, 2005; Given and Julien, 2005; Julien, 2000). Chiste et al. (2000) speak to this particular challenge by suggesting that librarians must use special "tactics" and "maneuvers" to "infiltrate" a professor's classroom (p. 202). 
Once librarians have overcome obstacles to gain time and space within a class, there is pressure to make the workshops meaningful so that professors value librarians' contributions enough to continually invite them into their classrooms. Providing poor instruction can do irrevocable damage to students' and professors' perceptions of a library and its services. As Deemer (2007) suggests, "if a freshman suffers through a canned $\mathrm{BI}$ [Bibliographic Instruction] presentation, irrelevant to her needs and delivered by a nervous librarian, then this student might make every effort to avoid the library at all costs" (p. 22).

In order for workshops to have their desired impact, students must be engaged and active in the lesson. The first five minutes are often deemed the most important of any time instructors (whether they are librarians or professors) spend with their class. In addition to setting the tone of the presentation and breaking the ice, the instructor must use this time to create a connection with the students, get them invested in the content, and challenge them to think critically (Deemer, 2007; Oswald and Turnage, 2000).

To get the students involved in information literacy workshops, librarians are increasingly using active learning techniques. Deemer (2007), for example, starts off his classes with what he calls an "anticipatory set," an engaging activity that helps students to anticipate where the class is going. In one such activity, he asks the students questions and provides time for them to write responses. By requiring students to write down their answers, they are forced to actively participate. This also provides instructors with a "quick visual cue" that they have the learners' full attention. The act of writing itself has been championed by educators as particularly useful, both in eliciting student engagement and promoting deeper thinking (Svinicki and McKeachie, 2011; Bonwell and Eison, 1991).

More specifically, Svinicki and McKeachie (2011) suggest that the act of writing down a question or concern is particularly useful for an instructor facing a new class for the first time. For example, in an ice-breaker activity they call "Question Posting," the instructor asks students to spend a minute writing down the concerns, issues or expectations they have regarding the class. The instructor then collects the questions and records these concerns and ideas for the class to see. This method of writing down and sharing questions helps both the teacher and the members of the class to become better acquainted with each other and introduces active participation to the classroom. The premise is that through this activity, the class "has learned that the teacher can listen as well as talk" (p. 24).

Educators of all levels of instruction have championed using student questions to direct classroom learning. Rather than having his high-school English students answer teacher-generated queries about class readings, Ensrud (1997) asks them to come up with their own questions. He finds that this approach places students "in control of their learning" and demonstrated that they are "capable of 'finding' meaning in literature and in others' ideas" (p.83). When teaching university-level Economics, Woldab (2013) uses student-generated questions to guide lessons in an attempt to move towards a constructivist approach to learning. He suggests that in generating their own questions, learners are forced to consider both what they know and what they do not know. They then use this awareness to begin the process of knowledge building.

In a similar fashion, Mayfield and French (2009) begin their one-shot library sessions by asking students what they would like to learn or be able to do by the end. By allowing their students to voice their own learning objectives and thereby "set the learning agenda" (p.81) for the session, Mayfield and French hope to increase intrinsic motivation. They observe that their students were "more responsive and eager to participate in the library instruction session when they set the learning agenda" (p. 84). 
Assessment in the IL Workshop

In addition to engagement, assessment is of utmost concern to instructors and to any librarians teaching workshops in academic settings. In Classroom Assessment Techniques: A Handbook for College Teachers, Angelo and Cross (1993) describe a variety of formative methods of assessment, used primarily to "inform teaching and improve learning, rather than to assign grades" (p.25). This type of assessment allows instructors to adjust their teaching in order to better meet the needs of their students. Based on feedback gathered from assessing a class, instructors can slow the pace of the lesson, clear up misunderstandings, or skip ahead. They suggest numerous examples of CATS (classroom assessment techniques) that can be used to collect data to measure and improve student learning. Many of these simple tools work well in information literacy workshops - as they can be done easily, with few materials and minimal set-up time required. Activities like the one-minute paper, the background knowledge probe and the muddiest point are often used in information literacy workshops (Angelo and Cross, 1993).

The literature suggests that many librarians use pre-assessment to determine students' library skills and past library experiences. They then use this information to create more relevant information literacy workshops, based on students' actual needs rather than librarians' assumptions of their knowledge and deficiencies. This is especially critical as many information literacy sessions are "one-shot" sessions that do not afford the opportunity to gauge students' needs over the course of a semester (Deemer, 2007). At Butler University (Indianapolis, IN), librarians developed a twenty-two question survey to determine incoming students' library skills as well as their attitude towards the library. They hoped the survey would document freshmen students' baseline library skills and past experience. The librarians report that the survey was successful in helping them adjust and tailor their "library basics" tutorial to be more relevant (Helmke and Matthies, 2004). At Texas Tech University, fifteen question pre- and post-assessment surveys were administered in eleven sections of a credit library course to measure students' learning and ongoing difficulties and to build a more effective course. Disappointing posttest results prompted the librarians to revise the content, intended goals and outcomes of the course to better address problem areas and more closely target actual gaps in students' knowledge (Hufford, 2010).

While pre and post-tests such as those described above, may provide valuable information, conducting extensive evaluations is not always possible, especially for librarians who primarily teach one-shot workshops. Librarians attempting to assess students in one-shot sessions face challenges, primarily because limited time and contact with the students forces them to focus all of their time and effort on the "delivery" part of instruction (Choinski and Emanuel, 2006; Deemer, 2007).

Time constraints are not the only factor librarians must consider when integrating assessment into their workshops. While recognizing the value of assessment, MacMillan (2005) considers if there is a way to do this type of evaluation without discouraging students. Traditional pre-test surveys are a concern for two reasons. In the first place, a survey full of library jargon may confuse students. Secondly, a low pre-test score may discourage students: "If, during their first encounter with library instruction, students do poorly on a pretest, that cannot enhance the students' confidence in their abilities. The negative effect may be compounded by badly designed tests that assess a student's understanding of library jargon rather than his or her ability to search for information" ( $p$. 517). MacMillan's concern is echoed by Svinicki and McKeachie (2011), who urge instructors to "avoid evaluation devices that increase anxiety" (p. 82). Rather than the traditional pre- or post-test survey, MacMillan (2005) encourages librarians to use 
activities that promote self-awareness of information literacy skills. In her own classes, she asks students to write a "resume" of their information skills (called an I SKILLS resume), in which they evaluate what they know about the library. This document can then be updated at the end of the workshop, as their skill-base grows. This type of activity creates awareness of what they know, what they don't know, and what knowledge they have gained.

When considering an ice breaker activity for in-class information literacy workshops, the authors wanted to use an activity that not only engaged the students in thinking about the library, but one that also valued their questions and their input. Rather than intimidating students by showing them what they did not know about the library, the authors wanted to provide a safe place for them to ask their questions. As an additional benefit, the authors hoped that the question activity would work as a quick assessment tool, providing them with a clearer idea of what thoughts, questions and concerns the students had about the library.

\section{Context for the Case Study}

McGill University is one of Canada's leading research-intensive universities. It comprises two campuses, eleven faculties, 300 programs of study and more than 36,000 students. The university is supported by twelve branch libraries, which are directly tied to the various faculties. McGill University Library does not have an information literacy coordinator and no information literacy course is offered across the curriculum; however, librarians individually work to coordinate information literacy instruction for their respective subjects. As such, the library system operates on a liaison model with every librarian being responsible for collection development, information literacy efforts, and reference expertise in particular subjects. The majority of librarian-led instruction takes place during general orientation sessions or within credit course class time, typically as one-shot information literacy workshops. Most one-shot workshops last between thirty minutes to one hour. The authors have been successful in liaising with their respective faculty members and advocating for time within the classroom to teach information literacy workshops.

\section{Questions Received}

The authors used the "burning question" activity in thirteen classes and received over two hundred questions during the course of a year. Classes were either in the disciplines of management or education and were typically introductory-level courses for first or second-year undergraduate students. The activity was primarily used in classes where the professor had simply asked for a general workshop to familiarize students with the library's services and resources rather than a workshop meant to prepare students for a particular research assignment. Ethics approval was obtained from McGill University's Research Ethics Board Office to collect these questions and disseminate the results.

Table 1: Classes in which the "burning question" activity was employed

\begin{tabular}{|l|l|l|l|}
\hline Course Name & $\begin{array}{l}\text { Number } \\
\text { of } \\
\text { Sections }\end{array}$ & Level & $\begin{array}{l}\text { Number of } \\
\text { students in each } \\
\text { class }\end{array}$ \\
\hline
\end{tabular}




\begin{tabular}{|l|l|l|l|}
\hline & Visited & & (on average) \\
\hline $\begin{array}{l}\text { Communication in } \\
\text { Education }\end{array}$ & 7 & Undergraduate & $25-30$ \\
\hline Health Education & 1 & Undergraduate & $45-50$ \\
\hline $\begin{array}{l}\text { Physical Education } \\
\text { Curriculum } \\
\text { Development }\end{array}$ & 1 & Undergraduate & $45-50$ \\
\hline $\begin{array}{l}\text { Communication in } \\
\text { Management }\end{array}$ & 3 & Undergraduate & $15-20$ \\
\hline $\begin{array}{l}\text { Fundamentals of } \\
\text { Public Relations }\end{array}$ & 1 & Graduate & $20-25$ \\
\hline
\end{tabular}

Overall Picture: What Questions did the Students ask?

The types of questions received ranged broadly from simplistic and directional in nature to research intensive. Many students were curious about the library's policies while some wanted to know about the types of resources and services available to them.

To get a better overall picture and help make sense of the types of questions students posed during the activity, the authors classified the collected questions into five main categories: Directional, Policy, Resources, Technical and Reference. The categories were adapted from a classification system developed by Sears (2001) for coding online chat reference queries, where she divides questions into the following categories: Directional, Reference, and Policy and Procedural. Table 2 provides specific examples of the questions asked to better illustrate the division of the five categories. [See Figure 1 for a breakdown of questions by type]

Table 2: Categories of questions received

\begin{tabular}{|c|c|}
\hline Type of Question & Sample Question \\
\hline Directional & $\begin{array}{l}\text { - Where is the bathroom? } \\
\text { - Where is the library? }\end{array}$ \\
\hline Policy & $\begin{array}{l}\text { - Can I renew my loaned books without visiting } \\
\text { the library? } \\
\text { - How does Inter-library loan work? }\end{array}$ \\
\hline Resources & $\begin{array}{l}\text { Does the library offer any workshops? } \\
\text { - Who can help me to format and put together } \\
\text { a paper at the library? }\end{array}$ \\
\hline Technical & $\begin{array}{l}\text { - How do I access library databases from off } \\
\text { campus? }\end{array}$ \\
\hline Research & $\begin{array}{l}\text { - What is the importance of "descriptors" when } \\
\text { using ERIC?" } \\
\text { - How do I find article on educational policies? }\end{array}$ \\
\hline
\end{tabular}

Figure 1: Overall question breakdown (\% of questions by question type) 


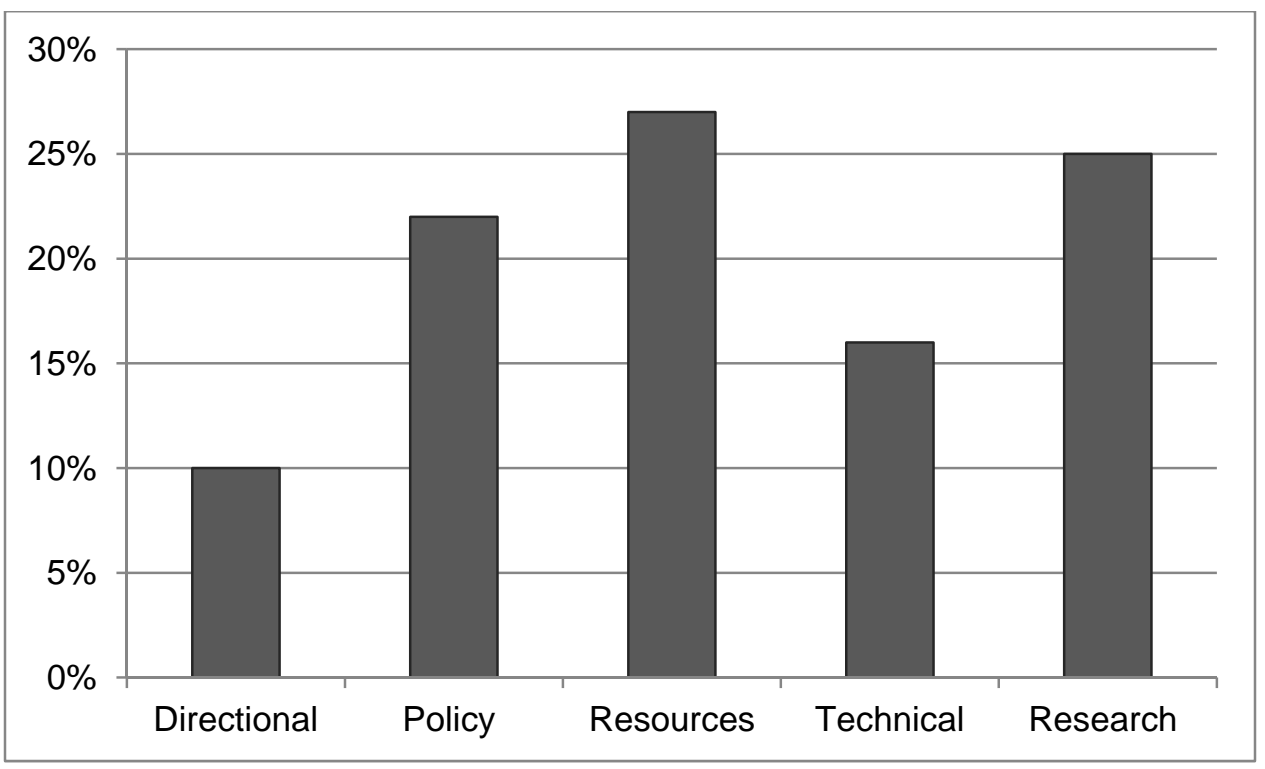

Questions Variations Between September/October \& Fall/Winter

Analysis also revealed that different types of questions were asked at different times during the academic year. For example, the number of Policy questions decreased by $11 \%$ from September to October, while the number of Research questions increased by $17 \%$. [See Figure 2]. Similarly, between the fall and winter semester, Policy questions decreased by $5 \%$ and Research questions increased by $10 \%$ [See Figure 3].

Figure 2: Types of questions asked: September vs. October

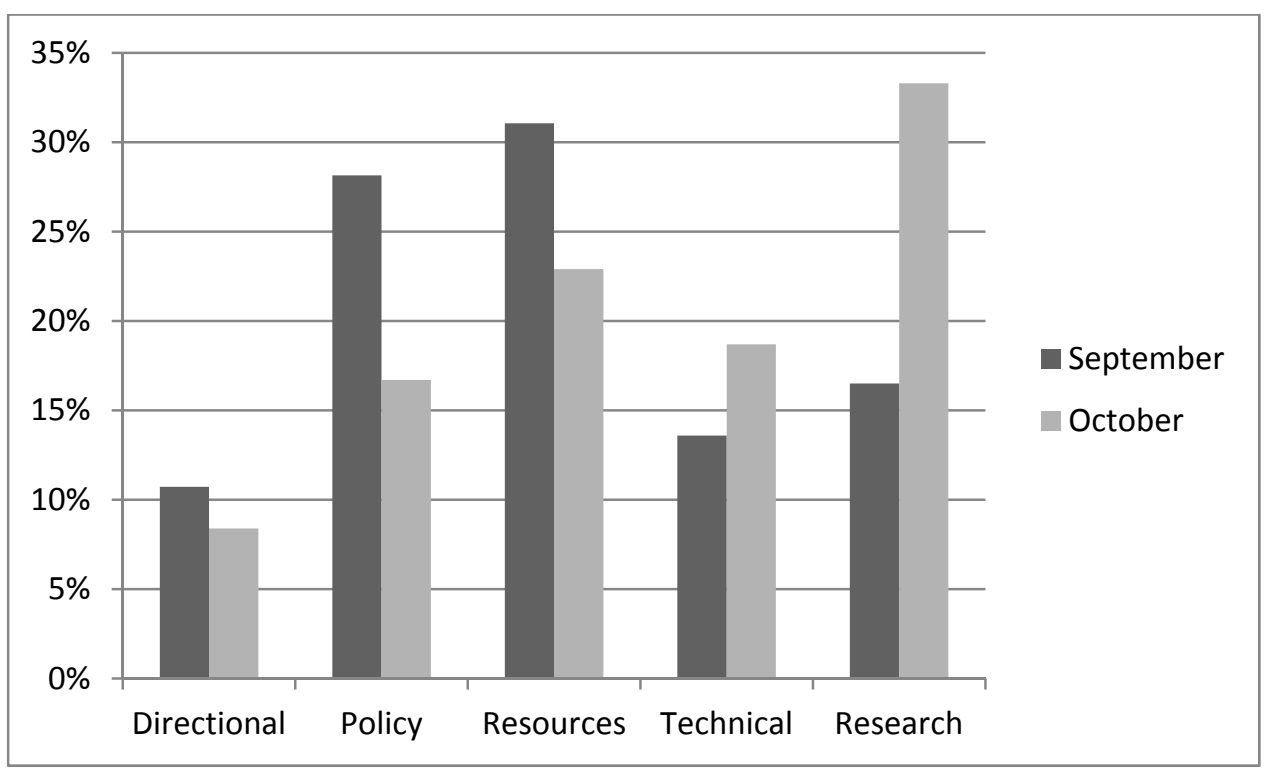

Figure 3: Types of questions asked: Fall vs. Winter 


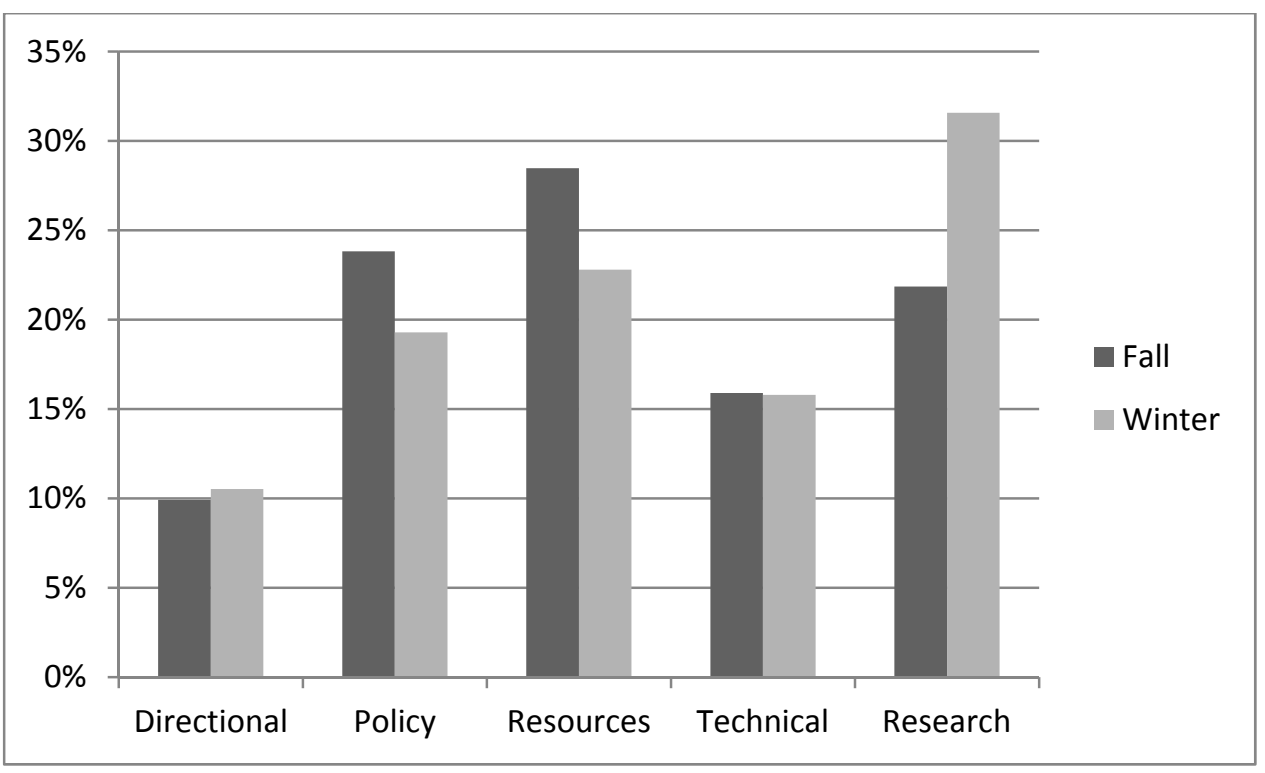

It was also not surprising to witness a change between fall and winter semesters as students returning to class in January have already had a term in which to become acquainted with library policies. The authors were, however, surprised to see a change between the types of question received in September and October, given the short time frame. Although further research needs to be undertaken before more conclusive remarks can be made, the results suggest that it may be useful for librarians to tailor their information literacy workshops to the month or semester in which they are given.

\section{Discussion}

\section{Challenging Assumptions \& Adapting Strategies}

In recent years, there has been a growing interest in collecting and analyzing questions clients ask at academic libraries in order to evaluate the type and level of service required in the physical library and online (Finnell and Fontane, 2010, Fennewald, 2006, Henry and Neville, 2008, Houlson et al., 2006, MacMillan, 2010, Meserve et al., 2009, Neville and Henry, 2009, LaGuardia, 1992). Analysis of questions has also been utilized as a method for assessing students' information literacy skills (Cordell and Fisher, 2010). Although the authors did not collect enough student questions to conduct a statistically significant analysis, they learned a considerable amount from this engaging activity. It was found that the "burning question" activity assisted in anticipating the students' information needs in their information literacy workshops and challenged assumptions about students' library knowledge. The activity also illuminated students' perspectives on the library and highlighted some of the key areas in which library services could be improved.

In several instances, the questions challenged the authors' assumptions about the students' library knowledge. For instance, in one upper-year class several students asked the question "Where is the library?" Understandably, prior to using the activity, the author assumed that all upper-level undergraduates would know the physical location of the library; however, the "burning question" activity highlighted the unique needs of that 
particular set of students. In this particular case the department's classrooms were on the other side of campus from their branch library, and students did not have the same daily exposure to the library as other units in the faculty. The author observed that the students seemed pleased to have an anonymous forum in which to ask such questions and also were relieved to know that others had posed the same question. Following the question about the location of the library, a number of other students volunteered that they had also never visited the library. Based on this information, the author recognized the need for the library to establish a closer relationship with this particular department. She set up weekly office hours within the department to address this need and made certain to emphasize some library basics in all other workshops taught for that particular department. One could argue that filling in gaps in basic knowledge about the library (where it is, what it is, and what it offers), is essential before jumping ahead to cover more advanced tasks such as database and catalogue searching as well as more complicated web navigation.

While the authors were surprised by some of the more rudimentary questions students posed, they were equally surprised to see the sophistication of some of the questions. For example, several students asked: "How do I know if a resource is scholarly or reliable?" and "Why are the library's articles better than Google's?". These types of questions were encouraging, as many librarians have lamented the "Google generation's" tendency to use whatever information source they can find quickly without assessing its quality (Randeree and Mon, 2011). Knowing that even new undergraduate students are concerned with the quality of information, encouraged both authors to take a step back in their approach to teaching students about finding information. Rather than jumping right into database searching, for future workshops the authors created activities that addressed such concerns as the difference between a scholarly and popular source and using Google to find reliable information. As members of the library's orientation committee, the authors were also able to ensure that such activities were incorporated into the workshops taught as part of the larger library-wide orientation program.

The authors also received a number of questions related to the library's book collection. For example, some of the more common questions included "how many books does the library have?" and "how many books can I take out?" While the first question could initially be considered a redundant question-something students might write for the sake of having something written-both questions highlight the extent to which students still associate libraries with books. Students did not often ask "how many databases does the library have" but rather they were interested in the collection of books. Such questions encouraged the authors to make time in all library workshops to promote the range of materials available at the library and to discuss the difference between the types of resources. For example, one of the authors began to incorporate into her workshops a mini class discussion about the scope of information resourcesfrom resources that provide general information to those that provide very specific information. This activity was also integrated into the campus-wide orientation workshops.

A significant number of students also had questions about how to access electronic materials from off-campus, highlighting an obvious need for students to have access to the library remotely. Additionally, this might indicate that configuring offcampus access is not clear or intuitive. In response, one author included more detailed instructions on off-campus access in her presentation slides and spent more time on this section of her workshops than previously.

The questions mentioned above highlight some of the most significant examples of how the authors' assumptions were challenged. In some cases, using the "burning 
question" activity led the authors to give very different workshops than the one they would have initially planned had they used a standard, prepared presentation.

\section{Making Sense of Student Questions Using Reference-Question Categorization}

Much of the literature related to analyzing student questions focuses on inperson or virtual reference interactions. Such studies helped the authors anticipate the types of questions that students might have about the library; however, by changing the venue of the question-asking from the reference desk to the classroom, the authors were uncertain if similar results could be expected.

As various systems of categorization are used to evaluate reference questions asked at the physical and virtual reference desk, it is difficult to cross-compare such studies; however, a few interesting trends seem to emerge in the literature. In their analysis of questions asked at the physical reference desk, both Henry and Neville (2008) and Meserve et al., (2009) compare student questions using the Warner Classification system. Both studies suggest is it more likely for students to ask lowerlevel questions (those they classify as "Non-resource-based" or "How to") rather than asking "Strategy-based" questions or those requiring a more in-depth consultation with a librarian.

When evaluating the types of questions asked in online chat reference, Sears (2001) observed a considerable lack of higher-level research questions. Her analysis found that approximately half of questions asked were ready-reference, while about onethird related to library policies and procedures. Of all 153 questions analyzed, only one research-level question was asked. Although using a different system of question classification, Houlson et al., (2006) similarly observe that simple "How to Find" questions are the most popular category of questions asked by undergraduate students via online chat reference. These findings were consistent with results from the authors' "burning question" activity: a minority of questions were research-based (25\%) while the remaining related to policy, resources, directions, or technical matters.

In contrast to the patterns observed in the reference-question studies mentioned above, Mayfield and French (2009) observe a different phenomenon in the classroom. When they asked students to come up with a list of what they would like to learn during a library workshop, most students expressed interest in learning about research-related topics. According to their study, the top five student-driven outcomes for four-year college students were: 1) Find periodical articles on a topic; 2) How to select and use keywords and refine/narrow search, use Boolean operators; 3) How to find books; 4) How to search faster, easier, more efficiently; and 5) Cite sources using APA/MLA. This was markedly different from the questions received during the authors' "burning question" activity. While some students asked how to cite, or how to properly differentiate sources, the majority of the questions were policy-based (e.g. how many books can I borrow), resource-based (e.g. what kind of databases does the library have), directional, or technical (e.g. how to connect to the library off-campus). The difference between the type of questions students asked in Mayfield and French's workshops and those asked in the authors' workshops is not surprising when one considers that Mayfield and French prefaced the activity by telling students the purpose of the session was the prepare them for an upcoming research paper. With this in mind, one would anticipate that the students' queries are strongly research-focused. This is in contrast to the authors' who did not begin their workshops by describing the purpose and tying the session to a particular assignment. Instead, students were strongly encouraged to write down any question they might have about the library beyond the context of a particular research assignment. Thus, the authors expected a range of questions more in-line with 
the variety received at the reference desk and in the studies of Sears (2001), Henry and Neville (2008), Meserve et al., (2009), and Houlson et al., (2006).

\section{Best Practices}

As discussed in the introduction, the "burning question" activity involves the librarian asking students to write down one question they have about the library and then using those student-generated questions to guide the workshop. This method changes the workshop from being primarily dictated by the librarian to a more student-focused and student-driven session.

This activity begins with the librarian handing out scrap paper to the students and giving them several minutes to record down a question about the library or research. As the students complete their questions, the librarian collects the papers and silently reads each question. To preserve anonymity, questions are read-aloud to the class only when all of the papers have been collected. Depending on the types of questions received, the librarian may tackle all questions off the top, or may choose to divide the questions into two categories: 1) general questions about the library (Directional, Policy, Resources and Technical) and 2) research questions. The general questions can then be answered one-by-one at the beginning of the workshop, while answers to the research questions may be naturally incorporated into a demonstration later on in the workshop. If time allows, the librarian may choose to repeat all the student questions at the end of the workshop to ensure that all questions have been answered. If students all have access to a computer, an alternative approach to the paper format would be to use an online form such as Titanpad.com. In a web-based format, students could anonymously type their questions and the librarian could then display the webpage with all the questions listed.

Although the authors have found this activity to be particularly useful for promoting student engagement in in-class information literacy workshops and for enhancing their own understanding of students' level of library knowledge, they recognize that a student-driven workshop is not without its challenges. Understandably, some librarians may be uncomfortable with the concept of giving control of the workshop over to students. When promoting this activity to other librarians, the authors have encountered a number of common concerns, including: What if the students write silly questions? What if I don't know the answer to a question? What if they write no questions? How do you successfully orchestrate this type of activity? The authors have developed a set of best practices for using this instructional activity to address the potential challenges.

\section{Logistical Issues}

After running this activity multiple times, the authors have several recommendations to help make the logistics more manageable. The authors also found that the "burning question" activity was most appropriate in classes where they had been asked to give a general library orientation and not a workshop geared towards a particular assignment. Given the time that it can take to run this activity, the authors did not find it feasible to combine this activity with a planned presentation for a specific class assignment.

Given the time-intensive nature of collecting the questions, reading them, and responding to them, this activity is best used in classes between fifteen to sixty students. 
In classes smaller than fifteen, the authors occasionally found that students were often too shy to write their questions, possibly feeling, given the small class size, that their questions were less anonymous. With classes larger than sixty, the activity becomes too difficult to orchestrate. In larger classes, it can be useful to have the students work in pairs to write a question between them. Another technique is to teach the class with a colleague. By having another librarian present, one librarian can facilitate the questiongathering, sort them into rough categories such as technology, research, directional, etc. and remove duplicate questions while the other librarian starts to respond to the questions. This approach allows the workshop to have more cohesion as questions of a similar nature are answered in proximity to each other. It also allows for the fast, quick questions (e.g. "how long can I borrow a book") to be dealt with before moving to more in-depth questions (e.g. "how do you find peer reviewed journals"). In one particular workshop, the two librarians placed tape on the back of each question as it was received and put them up on the chalkboard, removing them as each was answered.

If the librarian wanted to get the students further involved, several minutes could be provided for students to locate answers to their colleagues' questions before the librarian does. Students could either be assigned questions to answer or they could select whichever one interests them the most and pursue it. This approach works best when students all have access to computers.

An additional variation of this activity which allows for more control on the part of the librarian is to have the students write down their questions, give a prepared workshop and then return to the questions at the end to see if all their queries were covered; addressing at that point any which were not already discussed.

\section{Approaching Jokes \& In-depth Questions}

In each workshop there will inevitably be one or two questions that are clearly "fake" or meant as a joke. For example, while teaching an information literacy workshop for a course called Communication in Management, one of the authors received the following question: "Which library would you go to find books about bears?" There are two approaches to this type of question. The first is to simply ignore it since only the librarian and the student who wrote the question knew it was asked. Another approach is to use it as an opportunity for instruction. For example, for the question above, the authors used this question as an opportunity to tell the students about all the various branch libraries, and the vast collection of materials on all subject areas available at the university.

On occasion, the authors received challenging questions which required more extensive responses than would have been possible or appropriate in the context of the workshop (e.g., "What subjects are found on each floor or level of the Redpath Library?"; "What would you do to discover if an article was peer reviewed?"; "How to use databases"). While it is easy to feel overwhelmed when faced with a question that cannot comfortably be answered on the spot in the time allowed, the authors found that they could use this as an opportunity to promote the reference desk service and one-onone librarian assistance, showing the students how to get in touch with a librarian.

\section{Approaching a Low Response Rate}

When asking students to participate in an activity, there is always the risk that they will not cooperate. When an activity jump-starts a workshop, a lack of participation 
can certainly make the librarian feel vulnerable. Fortunately, the authors were pleasantly surprised to find this was rarely the case. In fact, they often experienced the opposite phenomenon, finding that in some classes many students wrote multiple questions, occasionally filling up both sides of their slips of paper. In general, the authors discovered that first-year students were the most enthusiastic participants in this activity. The authors recommend preparing a backup presentation in case the activity does not produce a significant response. The workshop can then proceed easily, and any questions that are received can be integrated into the prepared presentation. It's also important to remember that students may still have "burning questions" about the library, even if they do not participate in the activity by writing them down. If nothing else, this question ice-breaker opens up a dialogue between the librarian and the class, and reminds students that it is okay to ask a librarian questions. It can be useful to reinforce this notion of dialogue by reminding students to ask questions at any time throughout the workshop, or to pop into the library, send an email or call if other questions arise.

\section{Faculty Response}

The response by professors and instructors towards this activity was positive. However, the authors were careful to avoid this activity in workshops where the professor had made specific requests about content (e.g. a request to demonstrate a particular database, or a workshop that was intended to help students locate specific library resources for an assignment). In this way, professors who had anticipated a general library orientation workshop received a session as requested but in a new and engaging format. Several professors have specifically requested the "burning question" workshop in subsequent semesters, and one professor has suggested that in the future she would be happy to assign the question-writing activity as homework prior to the workshop, thereby allowing more time for question answering during the in-class session.

\section{Conclusion}

Student-centered instruction should begin with discovering what students need to know. The "burning question" approach outlined in this paper provides an effective and manageable way for librarians to create a student-directed learning experience that not only increases students' investment in the content but also provides librarians with a quick glimpse of what students actually want to need to know about the library and research.

Categorizing the "burning questions" using a reference-question model helped the authors to contextualize the results. While the authors assumed that they would receive queries on a wide-range of topics, they were occasionally surprised at the range of sophistication of the questions. Results suggest that the authors' students were predominantly interested in learning about library basics, as their questions focused on directional, policy, technical and resource issues rather than research-level concerns. By gaining a concrete understanding of the gaps in their students' knowledge, the authors were able to make on-the-spot decisions about what material to cover in the workshop. They were also able to better anticipate concerns or confusions for particular student groups and better address these needs through more tailored workshops or targeted library services. Finally, it allowed them, on occasion, to influence the content of larger teaching initiatives, including the workshops taught across campus as part of the library orientation program. 
As the activity was well-received by students and professors when following the best practices outlined, the authors continue to use "burning questions" as part of their overall information literacy toolkit. This case study has also led the authors to consider other information literacy teaching strategies in which students have greater control over the content that they are taught These include "choose your own adventure"-style presentations whereby several topics are suggested and the students vote on which topic they would like to see presented (Ramey, 1996). Another possibility for future iterations of the activity is to have professors collect students' "burning questions" and pass them onto the librarian prior to the workshop. While this would give librarians more time to prepare tailored content, it may take away from the ice-breaker nature of the activity. As discussed in the literature review, having students participate in a writing activity within the workshop helps to foster active learning and promote communication between the librarian and the students.

One concern that has been raised with this activity is that "students don't know what they don't know." That is, if the workshop is oriented by the students' questions, important or fundamental topics will be missed. While the concern is grounded, the authors found that by only using this activity in orientation or introductory information literacy workshops, students' questions covered or related to the basic themes the authors had hoped to cover anyway. Even if a particular topic was not indicated, librarians have the flexibility to include topics by relating them to one of the questions. Overall, the authors have found that this activity has provided students with a greater opportunity to engage with information literacy and to set up a positive precedent for information literacy instruction and interaction.

\section{References}

Angelo, T. A., Cross, K. P. (1993), Classroom Assessment Techniques : A Handbook for College Teachers, Jossey-Bass Publishers, San Francisco, CA.

Badke, W. B. (2005), "Can't get no respect: Helping faculty to understand the educational power of information literacy", Reference Librarian, Vol. 43 No.89/90, pp.63-80.

Bonwell, C. C., Eison, J. A. (1991), Active learning: Creating excitement in the classroom. ERIC Digest, ASHE-ERIC Higher Education Reports, Washington, DC

Chiste, K. B., Glover, A., Westwood, G. (2000), "Infiltration and entrenchment: Capturing and securing information literacy territory in academe", Journal of Academic Librarianship, Vol. 26 No.3, pp.202-208.

Choinski, E., Emanuel, M. (2006), "The one-minute paper and the one-hour class: Outcomes assessment for one-shot library instruction", Reference Services Review, Vol. 34 No.1, pp.148-155.

Cordell, R. M., Fisher, L. F. (2010), "Reference questions as an authentic assessment of information literacy", Reference Services Review, Vol. 38 No.3, pp.474-481.

Deemer, K. (2007), "Making the most of the one-shot you got", Community \& Junior College Libraries, Vol. 14 No.1, pp.21-26.

Ensrud, M. (1997), "Getting at what they want to know: using students' questions to direct class discussion," in Holden, J. and Schmit, J.S. (Eds.), Inquiry and the Literary Text: Constructing Discussions in the English Classroom, National Council of Teachers of English, Urbana, IL, pp. 79-86. 
Finnell, J., Fontane, W. (2010), "Reference question data mining: A systematic approach to library outreach", Reference \& User Services Quarterly, Vol. 49 No.3, pp.278-286.

Fennewald, J. (2006), "Same questions, different venue", The Reference Librarian, Vol. 46 No. 95, pp. 21-35.

Given, L. M., Julien, H. (2005), "Finding common ground: An analysis of librarians' expressed attitudes towards faculty", Reference Librarian, Vol. 43 No.89/90, pp.25-38.

Helmke, J., Matthies, B. S. (2004), "Assessing freshman library skills and attitudes before program development: One library's experience", College and Undergraduate Libraries, Vol. 11 No.2, pp.29-49.

Henry, D. B., Neville, T. M. (2008), "Testing classification systems for reference questions", Reference \& User Services Quarterly, Vol. 47 No.4, pp.364-373.

Houlson, V., McCready, K., Steinberg Pfahl, C. (2006), "A window into our patron's needs: Analyzing data from chat transcripts", Internet Reference Services Quarterly, Vol. 11 No.4, pp.19-39.

Hufford, J. R. (2010), "What are they learning? Pre- and post-assessment surveys for LIBR 1100, Introduction to Library Research", College \& Research Libraries, Vol. 71 No.2, pp.139158.

Julien, H. (2000), "Information literacy instruction in Canadian academic libraries: Longitudinal trends and international comparisons", College and Research Libraries, Vol. 61 No.6, pp.510-523.

LaGuardia, C. (1992), "Renegade library instruction", Library Journal, Vol. 117 No.16, pp.51-53.

MacMillan, M. (2005), "Open résumé: Magic words for assessment", College \& Research Libraries News, Vol. 66 No.7, pp.516-520.

MacMillan, M. (2010), "Mining e-mail to improve information literacy instruction", Evidence Based Library and Information Practice, Vol. 5 No.2, pp.103-106.

Mayfield, T. and French, K.F. (2011), "Letting the inmates run the asylum: student engagement in the progressive classroom", in LOEX Conference Proceedings 2009, Eastern Michigan University Digital Commons, Ypsilanti, MI, available at http://commons.emich.edu/loexconf2009/22/ (accessed 8 April 2013).

Meserve, H. C., Belanger, S. E., Bowlby, J., Rosenblum, L. (2009), "Developing a model for reference research statistics: Applying the "Warner Model" of reference question classification to streamline research services", Reference \& User Services Quarterly, Vol. 48 No.3, pp.247-258.

Neville, T. M. \& Henry, D. B. (2009), "Reference classification -- Is it time to make some changes?", Reference \& User Services Quarterly, Vol. 48 No.4, pp.372-383.

Oswald, T. A. \& Turnage, M. (2000), "First five minutes", Research Strategies, Vol. 17 No.4, pp.347-351.

Ramey, M. A. (1996), "Student choice: A modular approach to library instruction", Research Strategies, Vol. 14 No.4, pp.246-251.

Randeree, E., Mon, L. (2011), "Searching for answers in a Google world", Reference Librarian, Vol. 52 No.4, pp.342-351.

Sears, J. (2001), "Chat reference service: an analysis of one semester's data", Issues in Science and Technology Librarianship, 32, available: http://www.istl.org/01-fall/article2.html (accessed February 12, 2012).

Svinicki, M. D., Mckeachie, W. J. (2011), McKeachie's Teaching Tips: Strategies, Research, and Theory for College and University Teachers, Wadsworth, Cengage Learning, Belmont, CA. 
Woldab, Z.E. (2013), "Constructivist didactics in teaching economics: a shift in paradigm to be exemplary teacher", Academic Journal of Interdisciplinary Studies, Vol. 2 No. 1, pp. 197203. 